\title{
Identification and analysis of factors influencing climate change in terms of $\mathrm{CO}_{2}$ emissions
}

\author{
Jan Gutsche ${ }^{1,}{ }^{*}$, Eukasz Muślewski ${ }^{1}$, Anna Dzioba ${ }^{2}$ and Sergiy M atyukh ${ }^{3}$ \\ 1UTP University of Science and Technology, Faculty of Mechanical Engineering, Al. prof. S. \\ Kaliskiego 7, 85-796 Bydgoszcz, Poland \\ ${ }^{2}$ Cuiavian University in Wloclawek, Faculty of Social and Technical Sciences, Okrzei 94A, 87-800 \\ Włocławek, Poland \\ ${ }^{3} \mathrm{~K}$ hmel nitsky N ational U niversity, Instytutska Street, 11, K hmel nytskyi, 29000, U kraine
}

\begin{abstract}
It is commonly known that transport means rel ease exhaust gases into the atmosphere which poses a threat to the natural environment. Therefore, new requirements and stricter regulations on emissions of $\mathrm{CO}_{2}$ and other harmful substances are being introduced. This study presents an analysis of different emission sources of anthropogenic and natural origin. The analysis is supposed to show a real impact of transport related $\mathrm{CO}_{2}$ emissions on the natural environment. The work includes results of tests concerning application of biocomponents in motor vehicle fuels and their impact on the value of $\mathrm{CO}_{2}$ emission. Having in mind the analysis, it can be said that, as compared to other branches of economy and its natural sources, transport is not the major source of $\mathrm{CO}_{2}$ emission and application of biofuels is not a factor that is likely to significantly contribute to carbon dioxide emission reduction on a global scale.
\end{abstract}

\section{Introduction}

The natural environment consists of complex mechanisms which assure constant energy flow which is necessary to balance the impact of many factors determining the greenhouse effect phenomenon and environmental changes preserving sustainability of the global system. The major factor directly affecting occurrence of progressive changes is the climate which plays a key role in biological processes that determine evolution. However, this is biosphere that contributes to climate shaping, hence these phenomena are correl ated[1,2].

The earth atmosphere contains numerous elements and chemical compounds which dynamically exchange with the substances present on the planet surface. $M$ any greenhouse gases occur naturally in the environment and are not directly associated with human activity. These include: water steam, methane, nitric oxide and carbon dioxide.

Outside substances which are not natural components of the atmosphere are freons $[2,4]$.

Climate indexes are not real values but only their representations. Correct interpretation of the analyzed data set is crucial to acquire knowledge about the internal restrictions [2]. The first reports on $\mathrm{CO}_{2}$ concentration date back to 1937 and indicate that the value was 600 ppm (molecules per million) and the average temperature on the earth was 16 Celsius degrees, whereas data from the last sixty years shows an increase in $\mathrm{CO}_{2}$ concentration from $300 \mathrm{ppm}$ to $420 \mathrm{ppm}$. The results of measurements are not incorrect, and the difference results from application of a different measurement method, whereby it is burdened with other errors. Optical thickness of the atmosphere is defined by the greenhouse effect through the ratio of its particular layer radiation absorption and emission [4].

B ased on the literature analysis $[1,3,4]$, it can be said that the content of greenhouse gases does not reflect the climate change. Geological history of the earth proves climate variations between tropical and icy. These transformations occur once in several hundred million years.

\footnotetext{
* Corresponding author: jangutsche1@gmail.com
} 
Thus, it can be said that the earth climate has features of instability because volcanic eruptions can significantly affect the climate of continents.

Based on Stefan-Boltzman equation, it can be proven that the greenhouse effect depends on the temperature rather than the volume of heat which only enhances the transformations and temperature oscillations [4].

Thus, the analysis involves only assessment of the impact of selected chemical compounds on climatic changes which cause the greenhouse effect. Substances are divided into those related to human activities, that is, widely understood industry with the use of technical devices and substances of natural origin.

\section{Identification of factors determining emission of $\mathrm{CO}_{2}$}

A commonly used definition of a carbon footprint directly refers to climatic changes caused by a functional unit. The term was promoted by $M$ athis Wackernagel in 1996. Based on this, sources of emission, absorption, storing and consumption of environment harmful greenhouse gases are defined for all cycles of a product life cycle [6,7].

\section{Percentage share of greenhouse gases}

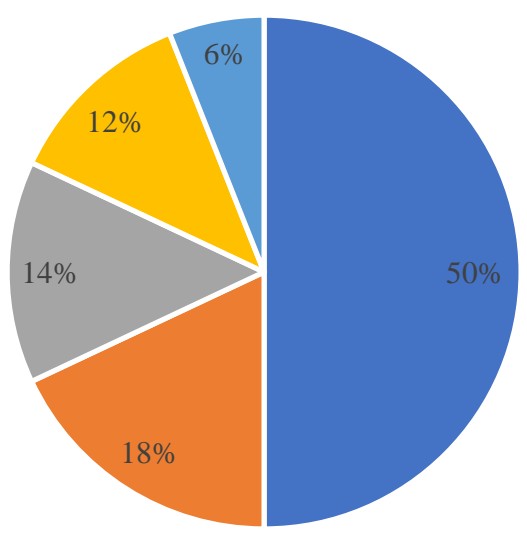

- Carbon dioxide $\quad$ Methane $\|$ Freons $\|$ Ozone $\|$ Nitric oxide

Fig. 1. Percentage share of greenhouse gases in the earth atmosphere [5].

The carbon footprint, being a measurable indicator, covers emission of carbon dioxide and the remaining chemical compounds defined as greenhouse gases, given as an equivalent of $\mathrm{CO}_{2}$. A unit to be used for determination of the carbon footprint is $t \mathrm{CO}_{2} e$, this measure is needed due to different effects of the remaining greenhouse gases, hence, a comparison with carbon dioxide is necessary to provide a reference point [6]. Based on coal extraction by Jastrzebska Coal Company (JSW), which is accompanied by emission of methane its equival ent was defined to be equal to [8]:

$$
1 \mathrm{t} \mathrm{CH}_{4}=28 \mathrm{t} \mathrm{CO}_{2}
$$

There are many causes of anthropogenic warming. Each of the above listed chemical substances has different properties and subsequently a different warming potential. It is assumed that concentration of gases in the atmosphere has changed in result of technological and industrial development, generally referred to as human activities, mainly due to increased 
exploitation of fossil fuels. There are some other, less conspicuous factors such as: deforestation, extension of rice fields, or animal husbandry [2].

\section{Greenhouse emission}

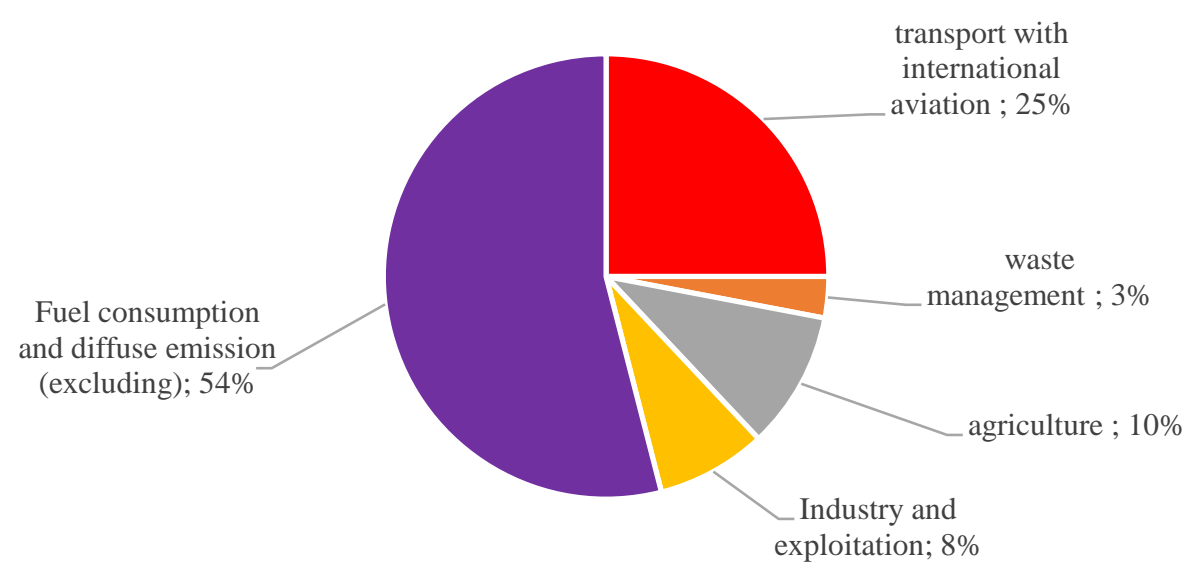

Fig. 2. A chart depicting the share of greenhouse gas emission from a given branch [9].

Nitric oxide and methane which occur in the global circulation of coal come also from natural sources such as, e.g. tropical forest bedding litter which is subjected to putrefaction [2]. Decomposition of organic matter associated with cow breeding causes emission of methane. A ccording to the United Nation Food and A griculture Organization, the processes that are involved in animal husbandry are responsible for $18 \%$ of global emission of all harmful greenhouse gases. A nnual emission of methane is estimated to be to be $89 \mathrm{mln}$ tons, which is consistent with $2.4 \mathrm{mld} t$ of $\mathrm{CO}_{2}$. Such an emission of gas accounts for about $40 \%$ of global emission of anthropogenic methane. Due to specific physical-chemical properties of $\mathrm{CH}_{4}$ and its GWP-Global Warming Potential, the period of its half-life is 12 years. It is necessary to determine a time interval for an analysis to be performed because the global warming decreases exponentially [2].

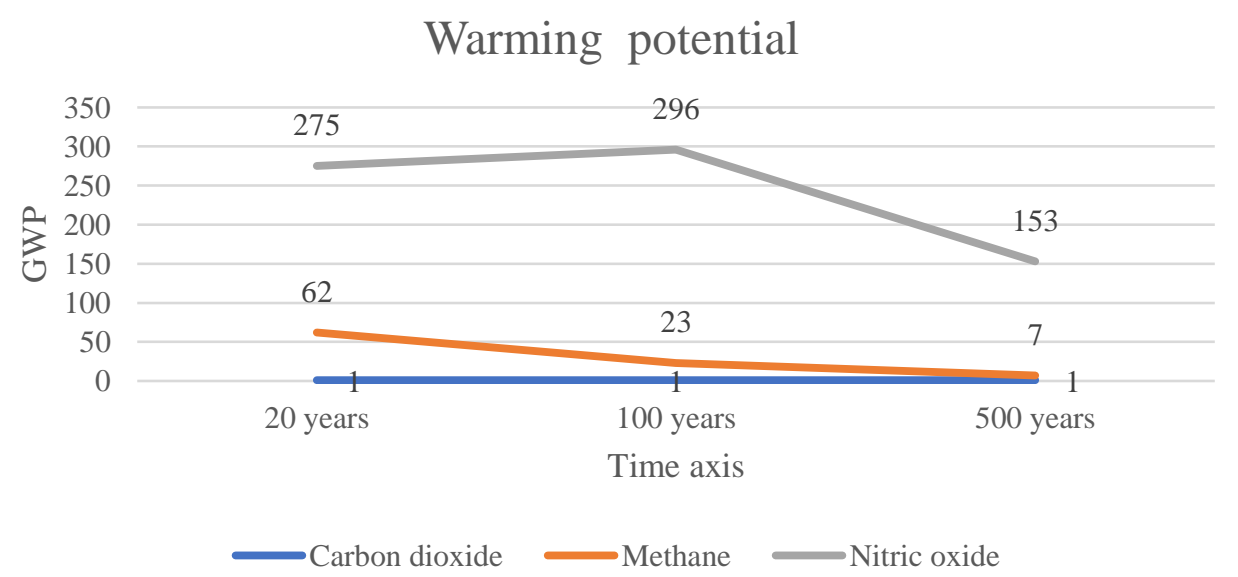

Fig. 3. Warming potential of selected greenhouse gases [2].

Thanks to the development of combustion engines, transport means have been revolutionized. Structural solutions in the field of component adjustment, structural materials 
or harmful substance emission reduction have been modified throughout ages. Due to different types of engine fueling, the percentage share of emitted exhaust gases is different. In the EU $72.8 \%$ of the total emission of transport related harmful substances comes from passenger cars, whereas heavy vehicles account for $18.8 \%$ of emission.

A ssuming that $5.1 \mathrm{mld}[\mathrm{t}]$ accounts for $100 \%$ of transport related CO2 emission, the global share of particular transport forms is as follows [16]:

- aviation $17 \%(0.867 \mathrm{mld}[\mathrm{t}])$,

- sea transport $6 \%(0.306 \mathrm{mld}[\mathrm{t}])$,

- road transport (passenger cars and trucks) $65 \%$ (3.315mld [t]) ,

- others (including rail transport) $12 \%(0.612 \mathrm{mld}[\mathrm{t}])$.

Due to more restrictive regulations on exhaust gas emission in the years 1990-2015, carbon dioxide emission was reduced by as much as 20\% [11]. Use of fossil fuels is responsible for emission of 43.1 billion tones of $\mathrm{CO}_{2}$ into the atmosphere, whereas the animal husbandry accounts for app. $5.56 \%$ of $\mathrm{CO}_{2}$ emission as compared to transport and industry [12]. M ore and more strict restrictions imposed on constructors of new vehicles require new technologies to be developed so that their vehicles can be homologated and legally move on public roads as once the concentration of $\mathrm{CO}_{2}$ exceeds the established limits the concern is required to pay a fine [11].

A the same time our planet is hit by disasters such as fires which significantly contribute to emission of harmful substances into the atmosphere. In 2019 the harmful emission caused by fires in A ustralia, A frica or A mazon was estimated to be 6 billion $t \mathrm{CO}_{2}$ [12]. However, $\mathrm{CO}_{2}$ emission caused by $\mathrm{K}$ rakatau was higher, than the emissions from all industrial activities since the beginning of mankind. The chart shows that eruptions have been taking place both during climate cooling and warming. There can be one conclusion which has been confirmed by leading scientists who are involved in research on climatic changes, that is, the level of $\mathrm{CO}_{2}$, including its emission caused by humans, does not play a significant role in the climate changes. [13].

Summing up, it is estimated that different activities of humans are responsible for approximately 30 billion tons of $\mathrm{CO}_{2}$ [16], these being:

- operation of power plants $28 \%(8.4 \mathrm{mld} \mathrm{t})$,

- biomass combustion $15 \%$ (4. mld t),

- industry $20 \%(6.0 \mathrm{mld} \mathrm{t})$,

- small businesses $20 \%(6.0 \mathrm{mld} \mathrm{t})$,

- transport 17\% (5.1mld t).

\section{Analysis of biocomponent additives to combustion engine fuels and their impact on $\mathrm{CO} 2$ emissions}

When considering the contribution of transport means to $\mathrm{CO}_{2}$ emission and its impact on the natural environment, biocomponents added to high pressure unit fuels appear to be of special interest. Plant oils subjected to transesterification are most commonly used as biocomponents [14-19]. Based on experimental tests, the actual impact of biocomponent additives to diesel oil has been established. An analysis of exhaust gases was carried out with the use of DMC 3.5t. vehicle. The high pressure unit 1.6 HDi is equipped with a Common Rail direct injection system. For the purpose of the tests, the computer controller used for adjusting the fuel dose and turbocharger underwent modification while different biocomponent contents were being added [14]. 
Table 1. Table including abbreviations used in the tests [13].

\begin{tabular}{|c|l|}
\hline \multicolumn{2}{|c|}{ Computer software modification } \\
\hline $\begin{array}{c}\text { Number of } \\
\text { settings }\end{array}$ & \multicolumn{1}{|c|}{ C } \\
\hline I & Manufactiurer's settings \\
\hline II & Fuel dose increased by $2 \%$ and air loading increased by $50 \mathrm{hPa}$ \\
\hline III & Fuel dose increased by $4 \%$ and air loading increased by $50 \mathrm{hPa}$ \\
\hline IV & Fuel dose increased by $6 \%$ and air loading increased by $50 \mathrm{hPa}$ \\
\hline V & Fuel dose increased by $6 \%$ and air loading increased by $150 \mathrm{hPa}$ \\
\hline \multicolumn{2}{|c|}{} \\
\hline M arking & Type of specimen \\
\hline A & Diesel fuel \\
\hline B & Mixture of 90\% diesel fuel and 10\% of fatty acid methyl esters \\
\hline C & Mixture of 70\% diesel fuel and 30\% of fatty acid methyl esters \\
\hline D & Mixture of 50\% diesel fuel and 50\% of fatty acid methyl esters \\
\hline E & $\begin{array}{l}\text { Mixture of 50\% diesel fuel and } 50 \% \text { of fatty acid methyl esters with a } \\
\text { fuel improver }\end{array}$ \\
\hline
\end{tabular}

A $n$ analysis of exhaust gases was performed by means of a temporarily legalized M GT5 device consistent with a directive of the European Parliament 22/2004WE. M easurements were repeated 30 times for maximal loading, on a chassis dynamometer [15].

Table 2. Percentage volume of $\mathrm{CO} 2$ in exhaust gases [15].

\begin{tabular}{|c|c|c|c|c|c|}
\cline { 2 - 6 } \multicolumn{1}{c|}{} & A & B & C & D & E \\
\hline I & 11.96 & 11.99 & 1.886 & 12.003 & 11.94 \\
\hline II & 12.143 & 11.696 & 12.103 & 12.406 & 11.98 \\
\hline III & 11.776 & 12.026 & 12.4 & 12.113 & 12.35 \\
\hline IV & 11.836 & 11.27 & 12.236 & 12.31 & 1.4 \\
\hline V & 12.62 & 12.326 & 12.142 & 12.606 & 1.4 \\
\hline
\end{tabular}

Based on the tests, the best results were found for a fuel dose increased by $6 \%$ and charging pressure increased by 0.05 bars for a mixture containing $90 \%$ of diesel fuel and $10 \%$ of fatty acid methyl esters [16].

\section{Volume percentage of $\mathrm{CO}_{2}$ emission}

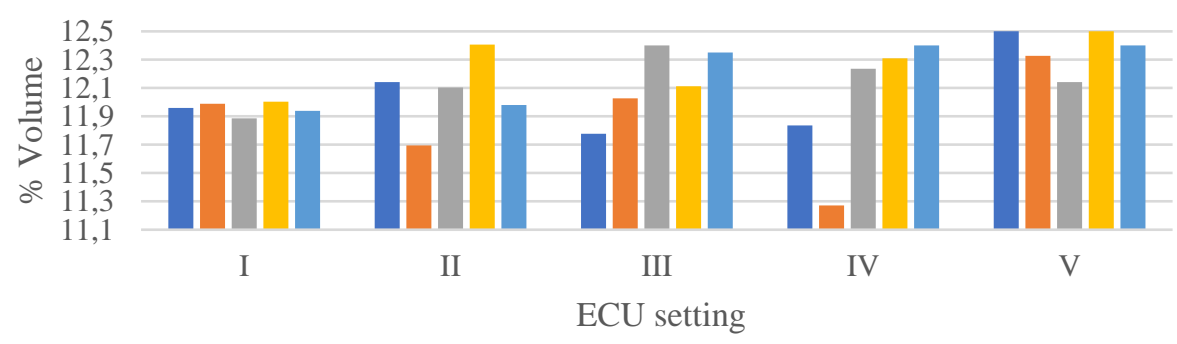

$$
\square \mathrm{A} \square \mathrm{B} \square \mathrm{C} \square \mathrm{D} \square \mathrm{E}
$$

Fig. 4. Graphic presentation of $\mathrm{CO}_{2}$ volume percentage in exhaust gases [13]. 
Based on the test results, it can be said that the highest $\mathrm{CO}_{2}$ emission reduction value as referred to the manufacturer's setting and 'pure diesel fuel' and modified ECU and a mixture of biocomponent modified fuel was found to be at the level of $1.036 \%$ [15].

The tested unit was characterized by average $\mathrm{CO}_{2}$ emission, at the level of $114 \frac{\mathrm{g}}{\mathrm{km}}$, whereas, the value estimated after modification was $109.867 \frac{\mathrm{g}}{\mathrm{km}}$ [20]. A ssuming that a vehicle covers 15 thousand kilometers yearly, $\mathrm{CO}_{2}$ emission will decrease by $61.56 \mathrm{~kg} \mathrm{CO}$.

\section{Conclusion}

Continuing the discussion in terms of economy, it needs to be noted that the European U nion has allocated as much as over a milliard Euro for fighting climatic change including $\mathrm{CO}_{2}$ emission. According to an initial report prepared for a special ONZ organ called, Intergovernmental Panel on Climate Change, the Earth temperature was estimated to grow by about $2 \mathrm{C}$ el si us degrees, whereas an estimate analysis of temperature changes has reveal ed that it has grown but only by $0.12^{\circ} \mathrm{C}$. Besides, it was found that in some locations the temperature has not changed since the years 950 - 1250, that is, hundreds of years before the industry and transport means appeared - excluding draught animals.

The process of adding biocomponents to diesel fuel to reduce $\mathrm{CO}_{2}$ emission can provide global effects, though it would require individual adjustment of each high pressure unit to a given fuel mixture. Reducing $\mathrm{CO}_{2}$ emission associated with room heating can provide much better effects. For instance, 3 persons who occupy $120 \mathrm{~m}^{2}$ and use a coal stove to provide heating of water and living space produce $8422.33 \mathrm{~kg} \mathrm{CO}$. When a different kind of fuel is used, e.g. LPG the average amount of $\mathrm{CO}_{2}$ emission drops down to $3008.5 \mathrm{~kg}$, which translates into $35.7 \%$ reduction as compared to hard coal [21]. A difference of over $5413 \mathrm{~kg}$ $\mathrm{CO}_{2}$, however, is consistent with emission reduction of three vehicles equipped with a modified computer, supplied with a biofuel, after coverage of the distance of $15000 \mathrm{~km}$ by each.

A the same time, it should be borne in mind that the subject matter analyzed in the study is complex and concerns the study of the impact of natural factors and technical aspects in the field of construction and operation of machines and devices. It is influenced by the processes of their design, used constructional and operating materials as well as applied diagnostic methods and conditions of their implementation [22-28].

\section{References}

1. B. Orębska-Starkel, L. Starkel, Efekt cieplarniany a globalne zmiany środowiska przyrodniczego (Zeszyty instytutu geografii i przestrzennego zagospodarowania PAN, 1991)

2. J. Cowie, Climate Change. Biological and Human Aspects (Cambridge Univesity Press, 2007)

3. T. Teluk, Mitologia Efektu cieplarnianego (Biblioteka Wolności, 2008)

4. M. A damczyk, Mity globalnego ocieplenia (Biblioteka W olności, 2019)

5. Artykuł Akademii Górniczo-Hutniczej im. Stanisława Staszica Krakowie, http://home.agh.edu.pl/ miska/dokum/cieplarniany.pdf

6. A. Kijewska, A. Bluszcz, Analiza poziomów śladu węglowego dla świata i krajów UE (Systemy wspomagania i inżynierii produkcji Zagadnienia Energomaszynowe i Bezpieczeństwo w Górnictwie, 2017)

7. T. Wiedmann, J. Minx, A Definition of 'Carbon Footprint' (Nova Science Publishers, 2008)

8. https://www.pb.pl/slad-weglowy-grupy-jsw-to-ponad-8-mln-ton-c02-961296

9. https://el ektrow 0z.pl/transport/emisja-co2-w-europie-najgorsze-sa-samochody-miesoprzemysl-a-moze-wulkany-dane/ 
10. https://naukaoklimacie.pl/fakty-i-mity/mit-krowy-emituja-wiecej-gazowcieplarnianych-niz-transport-117

11. M. Gis, Emisja dwutlenku wegla z transportu samochodowego cz.1 samochody klasy $L D V$ (W ydawnictwo ITS, 2017)

12. https://naukaoklimacie.pl/aktual nosci/2019-globalna-emisja-dwutlenku-wegla-wciazrosnie-394

13. www.longrangeweather.com

14. M. M arkiewicz, Ł. Muślewski, M. Pająk, Impact Of Biocomponent Additive To Diesel Oil On Values Of Elected Functional Parameters Of Transport Means (Polish Journal Of Environmental Studies, V ol. 29, 2020)

15. M. Markiewicz, Ł. Muślewski, Survey performance and emission parameters of diesel engine powered by diesel oil and fatty acid methyl esters using fuzzy logic techniques (Fuel, V ol. 277, 2020)

16. M. M arkiewicz, Ł. Muślewski, The Impact Of Powering An Engine With Fuels From Renewable Energy Sources Including Its Software Modification On A Drive Unit Performance Parameters (Sustainability, V ol. 11, 2019).

17. B. L andowski, M. Baran, Analysis of selected results of engine oil tests (M A TEC W eb of Conferences 302, 01010, 2019), 18th International Conference Diagnostics of Machines and Vehicles, pp.1-7 2019), https://doi.org/10.1051/matecconf/201930201010

18. B. Landowski, M. Baran, Analysis of changes in the value of selected lubricant characteristics during use (M ATEC W eb of Conferences 302, 01009, 2019), 18th International Conference Diagnostics of Machines and Vehicles, pp.1-8 (2019), https://doi.org/10.1051/matecconf/201930201009

19. B. Landowski, Ł. Muślewski, Numerical simulation of stochastic process as a model of technical object state changes (Engineering M echanics 2018 Proceedings, V ol 24 Book Series: Engineering M echanics, 24nd International Conference, may 14 - 17, 2018, Svratka, Czech Republic, Book of full texts, Institute of Theoretical and Applied M echanics of the Czech A cademy of Sciences, Prague, pp. 485-488 (2018)

20. https://francuskie.pl/peugeot-i-silniki-spelniajace-norme-euro-5/

21. http://vaillant-partner.pl/kalkulatory-on-line/kalkulator-emisji-zanieczyszczen/

22. J. Gronowicz, Ochrona środowiska w transporcie lądowym (ITeE, PoznańRadom, 2003)

23. M. Pająk, Ł. Muślewski, B. Landowski, A. Grządziela, Fuzzy identification of the reliability state of the mine detecting ship propulsion system (Polish M aritime R esearch, 26 (1), pp. 55-64, 2019)

24. R. Kostek, B. Landowski, Ł. Muślewski, Simulation of rolling Bering vibration in diagnostics (J ournal of V ibroengineering, Issue 8, V olume 17, 2015)

25. B. Landowski, Ł. Muślewski, Decision model of an operation and maintenance process of city buses (Proceedings of 58th International Conference of $M$ achine Design Departments - ICM D 2017, Publisher: Czech U niversity of L ife Sciences Prague, Czech Republic, pp. 188-193, 2017)

26. M. Łukasiewicz, T. Kalaczynski, J. M usiał, J. Shalapko, Diagnostics of buggy vehicle transmission gearbox technical state based on modal vibrations (Journal of V ibroengineering V olume 16, Issue 6, Page 3137-3145, 2014)

27. T. Kałaczyński, M. Łukasiewicz, J. Musiał Jacek, R. Polasik, M. Szczutkowski, N. Dluhunovych, J. Wilczarska, T. Kasprowicz, Analysis of the diagnostic potential research thermovision in the technical state of combustion engine injectors assessment 24th International Conference Engineering M echanics, Engineering M echanics; 18058248) 
28. P. Kolber, D. Perczyński, B. Landowski, S. Wawrzyniak, The control system of the stepper motor motion with positioning accuracy verification (Engineering M echanics 2016 Proceedings, Vol 22, B ook Series: Engineering M echanics, 22nd International Conference, may 9 - 12, 2016, Svratka, Czech Republic, B ook of full texts, Institute of Thermomechanics A cademy of Sciences of the Czech Republic, pp. 298-301, 2016) 